\title{
Endbulb synaptic depression within the range of presynaptic spontaneous firing and its impact on the firing reliability of cochlear nucleus bushy neurons
}

\author{
Yong Wang ${ }^{1,}{ }^{*}$, Chongyu Ren ${ }^{1}$, and Paul B. Manis ${ }^{2}$ \\ ${ }^{1}$ Division of Otolaryngology and the Program in Neuroscience, University of Utah, Salt Lake City, \\ UT 84132 \\ ${ }^{2}$ Department of Otolaryngology/Head and Neck Surgery and Deptartment of Cell and Molecular \\ Physiology, University of North Carolina at Chapel Hill, Chapel Hill, NC 27516
}

\section{Abstract}

The majority of auditory nerve fibers exhibit prominent spontaneous activity in the absence of sound. More than half of all auditory nerve fibers in CBA mice have spontaneous firing rates higher than spikes/sec, and some fibers exceeding $100 \mathrm{spikes} / \mathrm{sec}$. We tested whether and to what extent endbulb synapses are depressed by activity between 10 and $100 \mathrm{~Hz}$, within the spontaneous firing rates of auditory nerve fibers. In contrast to rate-dependent depression seen at rates $>100$ $\mathrm{Hz}$, we found that the extent of depression was essentially rate-independent $(\sim 35 \%)$ between 10 and $100 \mathrm{~Hz}$. Neither cyclothiazide nor $\gamma$-D-glutamylglycine altered the rate-independent depression, arguing against receptor desensitization and/or vesicle depletion as major contributors for the depression. When endbulb synaptic transmission was more than half-blocked with the P/Q $\mathrm{Ca}^{2+}$ channel blocker $\omega$-agatoxin IVA, depression during 25 and $100 \mathrm{~Hz}$ trains was significantly attenuated, indicating P/Q $\mathrm{Ca}^{2+}$ channel inactivation may contribute to low frequency synaptic depression. Following conditioning with a $100 \mathrm{~Hz}$ Poisson train, the EPSC paired pulse ratio was increased, suggesting a reduced release probability. This in turn should reduce subsequent depletion-based synaptic depression at higher activation rates. To probe whether this conditioning of the synapse improves the reliability of postsynaptic responses, we tested the firing reliability of bushy neurons to $200 \mathrm{~Hz}$ stimulation after conditioning the endbulb with a $25 \mathrm{~Hz}$ or $100 \mathrm{~Hz}$ stimulus train. Although immediately following the conditioning train, bushy cells responded to minimal suprathreshold stimulation less reliably, the firing reliability eventually settled to the same level $(<50 \%)$ regardless of the presence or absence of the preconditioning. However, when multiple presynaptic fibers were activated simultaneously, the postsynaptic response reliability did not drop significantly below $90 \%$. These results suggest that single endbulb terminals do not reliably trigger action potentials in bushy cells under "normal" operating conditions. We conclude that the endbulb synapses are chronically depressed even by low rates of spontaneous activity, and are more resistant to further depression when challenged with a higher rate of activity. However, there seems to be no beneficial effect as assessed by the firing reliability of postsynaptic neurons for transmitting information about higher rates of activity.

(C) 2010 Elsevier B.V. All rights reserved.

"Corresponding author: Yong Wang, University of Utah, Otolaryngology/Neuroscience Program, 3C120 School of Medicine, 30 North, 1900 East, Salt Lake City, UT 84132, Ph: 801-587-3846; Fax: 801-585-5744, yong.wang @ hsc.utah.edu.

Publisher's Disclaimer: This is a PDF file of an unedited manuscript that has been accepted for publication. As a service to our customers we are providing this early version of the manuscript. The manuscript will undergo copyediting, typesetting, and review of the resulting proof before it is published in its final citable form. Please note that during the production process errors may be discovered which could affect the content, and all legal disclaimers that apply to the journal pertain. 


\section{Keywords}

synaptic depression; endbulb of Held; auditory; spontaneous activity; firing reliability

\section{Introduction}

A prominent feature of the auditory nerve fibers (ANF) recorded in vivo in post-hearing animals is the presence of spontaneous firing in the total absence of stimulating sounds (Kiang, 1965). This spontaneous activity has a Poisson-like interspike distribution and is generated by stochastic and spontaneous neurotransmitter release at the ribbon synapse between the inner hair cell and the auditory nerve fiber (Sewell, 1984). Spontaneous firing is also influenced by the mechanoelectric transduction channels in the stereocilia of the hair cell (Farris et al., 2006). Although a correlation between spontaneous rates (SR) and individual ANF thresholds has been established and can partially explain the discrepancy between neural and psychophysical hearing dynamic range (Kiang, 1965; Liberman and Oliver, 1984), the influence of the ANF spontaneous activity on the reliability of synaptic transmission at the ANF and bushy neuron synapse, a "relay" synapse that is critically involved in sound localization, is not clear. Short-term synaptic depression at the endbulb terminal is activity dependent at high stimulation rates of $100-300 \mathrm{~Hz}$ (Oleskevich and Walmsley, 2002; Wang and Manis, 2008; Yang and Xu-Friedman, 2008). Recently it has been shown that depression at the endbulb synapse plays an intricate role in preserving and perhaps enhancing temporal firing precision (phase locking) of bushy neurons to phaselocked inputs (Yang and Xu-Friedman, 2009). In vitro, reliability of postsynaptic bushy neuron spikes can drop below $50 \%$ at firing rates $\geq 200 \mathrm{~Hz}$ when stimulated from quiescence (Wang and Manis, 2006). However, it remains unclear whether mature endbulb synapses are depressed at firing rates within the range of ANF spontaneous activity (generally $<100 \mathrm{~Hz}$ ). It is also not known whether the spontaneous activity, by depressing release, is beneficial or detrimental to the reliability of postsynaptic responses at rates of $200-300 \mathrm{~Hz}$ as commonly achieved in a normal acoustic environment. Studies in an analogous synapse, the calyx of Held in the medial nucleus of the trapezoid body (MNTB), suggest that synaptic depression occurs at rates below $100 \mathrm{~Hz}$, and is primarily due to presynaptic terminal $\mathrm{Ca}^{2+}$ current inactivation (Xu et al., 2007; Xu and Wu, 2005). At the calyx, the depression induced by presynaptic spontaneous activity appears to reduce the reliability of the suprathreshold synaptic transmission even though further synaptic depression is reduced following "spontaneous activity" preconditioning (Hermann et al., 2007; but see Lorteije et al., 2009). On the other hand, reduced synaptic depression may be beneficial to the reliability of synaptic transmission at the avian endbulb synapse (Brenowitz et al., 1998; Brenowitz and Trussell, 2001). Studies of single auditory nerve fibers recorded from mice indicate that spontaneous rates do not show the discrete multimodal distribution seen in other mammals such as cats (Liberman, 1982) and guinea pigs (Tsuji and Liberman, 1997). The majority of the auditory nerve fibers $(\sim 51 \%)$ have SR $>20$ spikes/sec (Taberner and Liberman, 2005). Furthermore, auditory nerve fibers can adapt their spontaneous rates as they adapt their firing dynamic range towards the most prevalent sound intensity encountered (Wen et al., 2009). In the current study, we examined synaptic depression at $10-100 \mathrm{~Hz}$, a range that encompasses the spontaneous firing rates of the majority of auditory nerve fibers recorded in vivo, and tested a possible functional role of this spontaneous activity in the reliability of suprathreshold synaptic transmission at the endbulb of Held synapse. 


\section{Materials and methods}

\section{Animal subjects}

CBA/Caj mice (Jackson Lab, Bar Harbor, ME) from in-house colonies, 22-56 days old (mean age $32 \pm 2$ days, $n=87$ ), were used for all electrophysiological recordings. No major developmental changes in the time course, conductance, or rectification of excitatory synapses have been found in animals of this age range (Wang and Manis, 2005). All experimental procedures were approved by the Institutional Animal Care and Use Committees at the University of Utah and the University of North Carolina at Chapel Hill.

\section{Cochlear nucleus slice preparation}

Mouse cochlear nucleus slices were prepared as previously described (Wang and Manis, 2005). Briefly, mice were anesthetized with ketamine (100 mg/kg)/xylazine (10mg/kg, i.p.), and then decapitated. The brainstem block containing the cochlear nuclei was immediately dissected out and immersed in pre-warmed $\left(34^{\circ} \mathrm{C}\right)$ dissecting artificial cerebrospinal fluid (ACSF), which differed from regular ACSF by containing high $\mathrm{Mg}^{2+}(3.8 \mathrm{mM})$ and low $\mathrm{Ca}^{2+}(0.2 \mathrm{mM})$. The recording ACSF contained (in $\left.\mathrm{mM}\right) 130 \mathrm{NaCl}, 3 \mathrm{KCl}, 1.25 \mathrm{KH}_{2} \mathrm{PO}_{4}$, 10 glucose, $20 \mathrm{NaHCO}_{3}, 2 \mathrm{CaCl}_{2}, 2 \mathrm{MgSO}_{4}$, and was bubbled with $95 \% \mathrm{O}_{2}$ and $5 \% \mathrm{CO}_{2}$ to a pH of 7.4. Parasagittal sections of $250 \mu \mathrm{m}$ cochlear nucleus slices were cut on an oscillating tissue slicer (Leica VT 1200). After incubation for at least $30 \mathrm{~min}$ at $34^{\circ} \mathrm{C}$ in recording ACSF, each slice was secured in the recording chamber while ACSF flowed through at a rate of $3-5 \mathrm{ml} / \mathrm{min}$. All recordings were made at $32-34^{\circ} \mathrm{C}$.

\section{Electrophysiological recordings}

Cells were visualized with an upright Zeiss Axioskop FS 2 Plus equipped with a waterimmersion lens (40x) and infrared differential interference contrast optics. To enhance the image contrast in slices from older animals, the field diaphragm was closed nearly all the way, and the condenser was aligned slightly eccentrically (Kachar, 1985). Patch electrode pipettes were pulled from borosilicate glass (KG-33, Garner Glass, Claremont, CA) with a Sutter P2000 puller (Sutter Instruments, San Francisco, CA), and had a resistance of $\sim 3 \mathrm{M} \Omega$ in the bath. Tips of recording pipettes were coated with Sylgard 184 (Dow Corning, Midland, MI) before use. The standard electrode solution used for current-clamp recordings contained (in mM): $110 \mathrm{~K}$-gluconate, $4 \mathrm{NaCl}, 20 \mathrm{KCl}, 10 \mathrm{HEPES}, 0.2 \mathrm{EGTA}, 4 \mathrm{Mg}^{2+}$-ATP, 10 creatine phosphate, and $0.3 \mathrm{GTP}$. The $\mathrm{pH}$ was adjusted to 7.2 with $\mathrm{KOH}$, and the final osmolarity $\sim 295 \mathrm{mOsm}$. For evoked EPSC recordings, a Cs ${ }^{+}$-based electrode solution containing $2.5 \mathrm{mM}$ QX314 (Tocris Cookson, Bristol, UK) was used to minimize contamination from potassium and sodium conductances. The solution contained (in $\mathrm{mM}$ ) $125 \mathrm{CsMeSO}_{3}, 15 \mathrm{CsCl}, 5$ EGTA, 10 HEPES, $4 \mathrm{MgATP}, 10$ creatine phosphate, $0.3 \mathrm{GTP}$, and was adjusted to $\mathrm{pH} 7.2$ with $\mathrm{CsOH}$. AMPA mediated EPSC in mature endbulb is indistinguishable with or without block of NMDA, GABA and glycine receptors (not shown), therefore no such blockers were included in routine recordings. Whole-cell recordings were made with an Axopatch 200B amplifier (Molecular Devices, Foster City, CA) under the control of pClamp 10 or in-house software written in MATLAB. Whole-cell access resistance was routinely less than $12 \mathrm{M} \Omega$ and compensated to $\sim 75 \%$ online with a 20 $\mu$ s lag time. The auditory nerve root was stimulated with a Grass S88 stimulator and SIU5 stimulation isolator (Warwick, RI), or Dagan stimlators (Minneapolis, MN) controlled by the data acquisition software. Stimulus pulses $(50 \mu \mathrm{sec})$ were delivered through a $75 \mu \mathrm{m}$ diameter concentric bipolar stimulating electrode (Frederick Haer, Bowdoin, ME). For voltage-clamp, the cells were held at $-55 \mathrm{mV}$ (estimated $\mathrm{Cs}^{+}$-electrode solution $\mathrm{V}_{\text {junc }} \approx-11.4$ $\mathrm{mV}$, not corrected). For each cell, a stimulus-response curve was measured and the stimulus strength was adjusted to be slightly above the minimal strength that reliably elicited a suprathreshold response. To be accepted for analysis, the EPSC elicited by the lowest- 
intensity stimulus had to be all-or-none and at least >2 nA (usually 3-4 nA) in amplitude, as expected for a large endbulb of Held synapse on to bushy cells (Isaacson and Walmsley, 1995). In the firing reliability test (Figure 4), a second, higher, stimulus strength was also used to activate more than one fiber, and the strength was based on stimulus-response curve of the cell. To test whether synaptic transmission at the endbulb of Held was mediated by terminal P/Q type $\mathrm{Ca}^{2+}$ channels, $50 \mathrm{nM}$ of $\omega$-agatoxin IVA (Alomone, Jerusalem, Israel) was added to the ACSF to block the synaptic transmission. Paired pulses and trains of pulses were used to estimate the release probability about $10 \mathrm{~ms}$ after a $100 \mathrm{~Hz}$ Poisson-distributed conditioning spike train $(450 \mathrm{~ms})$. To test the firing reliability, responses of bushy cells to stimulus trains (20 pulses) of nerve root shocks at $200 \mathrm{~Hz}$ delivered every $10 \mathrm{sec}$ for 20 times were tested in current clamp (I-clamp fast mode on Axopatch 200B) either in a rested state or $15 \mathrm{~ms}$ after $500 \mathrm{~ms}$ conditioning trains of 25 or $100 \mathrm{~Hz}$. Firing probability for each shock in the train was calculated as the fraction of trials on which the cell spiked over 20 trials. Cells were held at their resting membrane potentials and the estimated $\mathrm{V}_{\text {junc }}$ of -11.9 $\mathrm{mV}\left(\mathrm{K}^{+}\right.$-gluc internal) was not corrected in the results.

\section{Data analysis}

Evoked EPSC amplitudes were measured from current baseline to the peak of the event. EPSC amplitudes were then normalized to the average amplitude of the first EPSC in the train. Statistical analysis ( $t$-test or ANOVA) was performed in Graphpad Prism 4.0 (San Diego, CA). Significance was determined for $p$ values of less than 0.05. Data are presented as mean $\pm \mathrm{SEM}$.

\section{Results}

\section{Synaptic depression at lower rates}

In contrast to rate-dependent depression for stimulus trains at $100 \mathrm{~Hz}$ and above (Wang and Manis, 2008; Yang and Xu-Friedman, 2008), we did not observe major differences in the magnitude of depression at the end of short $10-100 \mathrm{~Hz}$ stimulus trains (Figure 1A, B). The final depression levels after 11-15 shocks were similar at $0.65 \pm 0.06,0.60 \pm 0.05,0.67 \pm 0.03$ and $0.66 \pm 0.05$ of the initial EPSC amplitude for 10, 25, 50 and $100 \mathrm{~Hz}$ respectively (Figure $1 \mathrm{~B}$ inset, $\mathrm{p}>0.05$, 1-way ANOVA with post-hoc multiple comparison). Receptor desensitization would be expected to be more prominent at a higher stimulation rate because of a finite desensitization recovery time ( 10 msec) (Chanda and Xu-Friedman, 2010;

Raman and Trussell, 1992). However, the depression levels at 25 and $100 \mathrm{~Hz}$ were identical even when measured in the presence of $50 \mu \mathrm{M}$ cyclothiazide ( $p=0.95$ for $25 \mathrm{~Hz}$ and $p=0.61$ for $100 \mathrm{~Hz}, \mathrm{n}=6$, Figure 2A), which reduces AMPA receptor desensitization. This suggests that the depression at these frequencies does not depend on receptor desensitization. To further probe if vesicle depletion at the endbulb played a major role in synaptic depression for stimulation rates $\leq 100 \mathrm{~Hz}$, we used a low-affinity competitive AMPA receptor antagonist $\gamma$-D-glutamylglycine ( $\gamma$-DGG). $\gamma$-DGG has a dual effect on EPSC depression (Chanda and Xu-Friedman, 2010). On the one hand, because of the fast-off rate of the drug, $\gamma$-DGG should block less when transmitter concentration is high whereas its effect is larger when transmitter concentration is low (Wadiche and Jahr, 2001; Wu et al., 2007). Thus, it is expected that $\gamma$-DGG would enhance the synaptic depression during the train if subsequent transmitter release is reduced. On the other hand, $\gamma$-DGG would attenuate synaptic depression during the train if receptor desensitization plays a major role because a portion of the $\gamma$-DGG-bound receptors are protected from desensitization and made available to newly released transmitters. Since the effects of desensitization are minimal at the low stimulation rates used here, the effects of $\gamma$-DGG should be largely on transient transmitter release. If a faster depletion of vesicle pools reduces subsequent transmitter release more rapidly at a higher rate, it is expected that $\gamma$-DGG would enhance synaptic depression more at a higher 
stimulus rate. Although we found that the synaptic depression was enhanced in the presence of $1 \mathrm{mM} \gamma$-DGG (Chanda and Xu-Friedman, 2010), the steady-state depression at the end of the trains was comparable when comparing synaptic depression of $25 \mathrm{~Hz}$ trains to that of $100 \mathrm{~Hz}$ trains even in the presence of $\gamma$-DGG (Figure 2B). The final synaptic depression level in the presence of $1 \mathrm{mM} \gamma$-DGG was $0.49 \pm 0.02$ for $25 \mathrm{~Hz}$ vs. $0.48 \pm 0.03$ for $100 \mathrm{~Hz}$ train $(\mathrm{p}=0.38, \mathrm{n}=5$, paired $t$-test), whereas the final level was $0.65 \pm 0.02(25 \mathrm{~Hz})$ vs. $0.61 \pm 0.03(100 \mathrm{~Hz})$ without $\gamma-\mathrm{DGG}(\mathrm{p}=0.22)$. Thus, it is unlikely that depletion of the releasable vesicle pool makes a major contribution to depression at these low rates. An alternate hypothesis for the reduction in EPSC amplitude at low rates could be the inactivation of $\mathrm{P} / \mathrm{Q}$ type $\mathrm{Ca}^{2+}$ channels. Inactivation of these channels depends on $\mathrm{Ca}^{2+}$ influx (Forsythe et al., 1998) and has been shown to contribute to synaptic depression at stimulation rates $<100 \mathrm{~Hz}$ at the MNTB calyceal terminal (Forsythe et al., 1998; Nakamura et al., 2008; Xu and $\mathrm{Wu}, 2005)$. In young mice ( P13), endbulbs use a mixture of $\mathrm{N}$ and P/Q type calcium channels (Oleskevich and Walmsley 2002). In the MNTB calyx, there is a transition from mixed $\mathrm{Ca}^{2+}$ channels to principally P/Q type $\mathrm{Ca}^{2+}$ channels with development 12 (Iwasaki and Takahashi, 1998). We thus tested whether the synaptic transmission at mature endbulbs also reflects that transition, and can be completely blocked by P/Q type calcium channel blocker $\omega$-agatoxin IVA. Eight to ten minutes after bath application of $50 \mathrm{nM} \omega$-agatoxin IVA, synaptic transmission at the endbulb was blocked by $>90 \%$. Evoked EPSCs were $4.10 \pm 0.71 \mathrm{nA}$ and $0.27 \pm 0.06 \mathrm{nA}$ before and after bath application of $\omega$-agatoxin IVA ( $\mathrm{p}=0.005, \mathrm{n}=5$, paired $t$-test, Figure $2 \mathrm{C}$ left bottom). A complete block of release was observed with longer incubation times or higher drug concentrations (data not shown). Thus, synaptic transmission at mature endbulbs is mediated by P/Q type calcium channels (Lopez et al., 2003; Roehm et al., 2008). P/Q Ca ${ }^{2+}$ channel inactivation depends strongly on intracellular $\mathrm{Ca}^{2+}$ influx (Forsythe et al., 1998) and involves $\mathrm{Ca}^{2+}$ binding to the $\mathrm{N}$-terminal of the channel-bound calmodulin (Chaudhuri et al., 2007; Lee et al., 2003). If $\mathrm{P} / \mathrm{Q} \mathrm{Ca}^{2+}$ channel inactivation plays a role in depression, then reducing the $\mathrm{P} / \mathrm{Q} \mathrm{Ca}{ }^{2+}$ channel inactivation through partial block of $\mathrm{Ca}^{2+}$ influx with $\omega$ agatoxin IVA should reduce synaptic depression. All the cells $(n=6)$ showed significant reduction of synaptic depression at the end of the $25 \mathrm{~Hz}$ train $(\mathrm{p}<0.001$, Figure $2 \mathrm{C}$ ) when the initial EPSC was blocked more than $50 \%$ ( $71 \%$ on average) by $~ 40 \mathrm{nM} \omega$-agatoxin IVA. Synaptic depression at the end of $100 \mathrm{~Hz}$ trains was similarly reduced, even though an initial facilitation was observed (Lee et al., 2000; Lee et al., 2003). An identical decrease in EPSC depression during the train was also seen when synaptic transmission was reduced to a similar extent by lowering external $\mathrm{Ca}^{2+}$ concentration (data not shown). Taken together, our results suggest that $\mathrm{Ca}^{2+}$ channel inactivation may play a significant role in endbulb synaptic depression at low activation rates $(<100 \mathrm{~Hz})$ similar to what has been observed in the calyceal terminals (Xu and $\mathrm{Wu} 2005)$.

\section{Reduced release probability after Poisson spike trains}

In total silence, the average spontaneous firing rate of ANFs in CBA mice is $\sim 25 \mathrm{~Hz}$ (Taberner and Liberman, 2005), and it is almost certain that the basal ANF firing rate is higher in normal acoustic environments. Spontaneous firing rates of auditory nerve fibers recorded from CBA mice can exceed $100 \mathrm{spike} / \mathrm{sec}$. We thus tested the hypothesis that the endbulb synapses may operate in a tonically depressed state. Since spontaneous activity in the auditory nerve follows a Poisson-like distribution of interspike intervals with a refractory period (Rodieck et al., 1962), we generated stimulus trains with Poisson-distributed interspike intervals with a dead time of $0.7 \mathrm{msec}$ that resemble in vivo spike trains of ANFs. To test release probability and synaptic depression after the Poisson trains, we measured evoked EPSC paired-pulse ratio (PPR) after a $450 \mathrm{~ms}$ Poisson conditioning train at $100 \mathrm{~Hz}$. Compared to terminals stimulated from a resting state, the PPR was increased from $0.88 \pm 0.03$ to $0.97 \pm 0.05$ ( $\mathrm{p}=0.06, \mathrm{n}=8,1$-tailed $t$-test) for $3.3 \mathrm{~ms}$ interval; from $0.83 \pm 0.04$ to 
$0.93 \pm 0.04$ ( $\mathrm{p}=0.01$ ) for $5 \mathrm{~ms}$ interval; and from $0.93 \pm 0.04$ to $1.04 \pm 0.04$ ( $\mathrm{p}=0.04$ ) for $10 \mathrm{~ms}$ interval after the Poisson trains (Figure 3A). Moreover, following the Poisson conditioning train, the rate of depression was significantly reduced when tested with a short train of 4 pulses at $200 \mathrm{~Hz}$ ( $\mathrm{p}<0.0001, \mathrm{n}=8,2$-way ANOVA with post hoc test) (Figure 3B). These results indicate that the release probability was lower after the conditioning train, and consequently the synapse becomes more resistant to further depression. It is possible that there is a reduction in the size of the releasable vesicle pool with on-going, sustained activity at a moderate rate $(\mathrm{eg}, 100 \mathrm{~Hz})$. However, a simple reduction in the pool size should not directly affect release probability (Sullivan, 2007) until the pool is depleted.

\section{Rapid decline of firing reliability in bushy neurons after presynaptic conditioning}

Sustained maximum sound driven firing rates recorded from auditory nerve fibers in CBA mice ranges between 200 and 400 spikes/sec (Taberner and Liberman, 2005). Since the majority of auditory nerve fibers have spontaneous activity, endbulb synapses should be in a chronic state where depression is reduced. We tested whether the "spontaneous-activity" induced depression of the synapse improves the reliability of synaptic transmission at the endbulb, as would be expected from previous studies in chickens (Brenowitz et al., 1998; Brenowitz and Trussell, 2001). Since there are, as yet, no known electrophysiological means to separately identify the spherical and globular bushy neurons, and there is uncertainty regarding the ANF convergence ratio on bushy neurons in mice (Oertel, 1985; but see Cao and Oertel 2010), we combined all type II neurons (bushy cells; Oertel, 1983; 1985) together in our study. A recent study has demonstrated that sibling innervation of individual bushy neurons can be isolated in slices (Yang and Xu-Friedman 2009). Similar to prior studies, we were able to obtain a distinct 2-step stimulus-response pattern in bushy neurons in current clamp after using the classic cell classification scheme (Oertel, 1983; 1985). As shown in Figure 4A (middle), we could discern suprathreshold spike responses with 2 distinct depolarization rising slopes (inset), indicating the presence of multiple underlying EPSCs. In this cell, the mean maximal action potential rising slope of step- 2 spikes was about twice that of step-1 spikes $(207 \mathrm{mV} / \mathrm{ms} v s .115 \mathrm{mV} / \mathrm{ms}$, indicated by the red filled squares in the inset). Similarly, we could capture the underlying EPSCs transitioning from initial step-1 amplitude to a larger step-2 amplitude using the same stimulus regimen after switching from current-clamp to voltage-clamp in the same cell (Figure 4A, lower trace). The simplest interpretation of this stimulus-response pattern is that increasing the stimulus level recruited more converging fibers onto the same neuron. Of the 21 bushy neurons tested this way, 8 cells (38\%) had single step pattern, 12 cells (57\%) had 2-step pattern, and in only 1 cell $(5 \%)$ did we see evidence for more than 2 steps without saturating the stimulator (150 volts). We could not be entirely certain that 1-step cells were innervated by a single auditory nerve fiber, because it is possible that converging fibers that are physically close together have nearly identical activation thresholds and might not be distinguished by this method. However, the first step in cells that show the 2-step pattern likely represented the single fiber activation because the observed $1^{\text {st }}$ step EPSC amplitude was similar to that of isolated single fiber EPSCs (Yang and Xu-Friedman 2009). We focused on cells with the 2-step pattern to probe the firing reliability when single and multiple fibers were activated. Because the degree of synaptic depression below $100 \mathrm{~Hz}$ was identical when using either Poisson or regular trains (Wang and Manis 2008; Hermann 2007), we used $25 \mathrm{~Hz}$ and $100 \mathrm{~Hz}$ regular stimulus trains $(500 \mathrm{~ms})$ to condition the endbulb synapses. Fifteen milliseconds following the conditioning train, we stimulated the $\mathrm{ANF}(\mathrm{s})$ with a $200 \mathrm{~Hz}$ test train and measured the bushy cell firing reliability over 20 trials. When a single presynaptic fiber (suprathreshold, step-1 stimulus strength) was activated, terminals conditioned with either $25 \mathrm{~Hz}$ or $100 \mathrm{~Hz}$ showed a greater decline of firing reliability when compared to unconditioned synapses (Figure 4C and D). However, independent of conditioning, the firing reliability eventually settled to the same level. Although the degree of steady-state firing probability varied from 
cell to cell, all 6 cells tested showed a similar pattern (Figure 4C). As a group, when a single fiber was activated, steady-state firing probability (average of the last 3 pulses) reduced to less than $50 \%(0.45 \pm 0.14,0.30 \pm 0.08$, and $0.36 \pm 0.10$ respectively for none, $25 \mathrm{~Hz}$ and 100 $\mathrm{Hz}$ conditioned trains; $\mathrm{p}=0.64$, 1-way ANOVA). Even though a large number of postsynaptic spike failures were seen, synaptic failures were never observed (Figure 4B). The rate at which the steady-state level was reached was different between the conditioned (either 25 or $100 \mathrm{~Hz}$ ) and unconditioned groups. A single exponential fit (dotted lines) yielded time constants of 55, 28 and $14 \mathrm{msec}$ respectively for unconditioned, $25 \mathrm{~Hz}$ and 100 $\mathrm{Hz}$ train-conditioned groups. Although it was not quite statistically significant ( $\mathrm{p}=0.058,2$ way ANOVA), all cells conditioned with a $25 \mathrm{~Hz}$ train showed a slightly slower decay of firing probability compared to those conditioned with a $100 \mathrm{~Hz}$ train. In contrast, when multiple fibers were activated (step-2 strength), postsynaptic bushy neurons fired over $90 \%$ of the time throughout the $200 \mathrm{~Hz}$ test train, regardless of conditioning regimens. As a group, the steady-state firing probabilities (average of the last 3 pulses) were $0.96 \pm 0.03$, $0.92 \pm 0.05$ and $0.84 \pm 0.09$ in unconditioned, $25 \mathrm{~Hz}$ and $100 \mathrm{~Hz}$ conditioned cells respectively (1-way ANOVA, $\mathrm{p}=0.4$ ). Nevertheless, the rate to reach the final level was different between the groups (2-way ANOVA p<0.0001), even between $25 \mathrm{~Hz}$ and $100 \mathrm{~Hz}$ conditioned groups $(\mathrm{p}<0.0001)$.

\section{Discussion}

We have shown that presynaptic activity in the range of $10-100 \mathrm{~Hz}$ induces a moderate synaptic depression at the endbulb terminal in mature mice that is rate-independent. Neither presynaptic vesicle depletion nor postsynaptic receptor desensitization seems to play a major role in the depression at these rates. Even though synapses in this chronically depressed state are more resistant to further depression when challenged with a higher rate of activity, there seems to be no beneficial effect, as assessed by the firing reliability of postsynaptic neurons for transmitting information about higher rates of activity.

\section{Mechanisms of endbulb synaptic depression at firing rates below $100 \mathrm{~Hz}$}

It is surprising to see that synaptic depression at activation rates below $100 \mathrm{~Hz}$ is rate independent. This would not be expected if the depression is primarily caused by receptor desensitization and/or presynaptic vesicle depletion (Chanda and Xu-Friedman, 2010; Wang and Manis, 2008; Yang and Xu-Friedman, 2008). Receptor desensitization is unlikely to be a major factor in the depression at $10-100 \mathrm{~Hz}$ because $50 \mu \mathrm{M} \mathrm{CTZ}$ has no effect on the synaptic depression, and also because the interstimulus intervals at these low rates are longer than the desensitization recovery time constant ( 10 ms) (Raman and Trussell, 1995; Yang and Xu-Friedman, 2008). Depression resulting from depletion of releasable vesicle pools should also depend on activation rates (Wang and Manis, 2008), but we did not observe this, even in the presence of $\gamma$-DGG where receptor saturation is greatly reduced (Chanda and $\mathrm{Xu}$-Friedman, 2010). Since synaptic transmission at the endbulb can be completely blocked by $\omega$-agatoxin IVA, and synaptic depression can be attenuated by a significant reduction of $\mathrm{Ca}^{2+}$ influx when $\mathrm{Ca}^{2+}$ channels are partially blocked, it is likely that the observed depression was due to the inactivation of the terminal $\mathrm{P} / \mathrm{Q}$-type $\mathrm{Ca}^{2+}$ channels, which in turn causes a decrease in $\mathrm{Ca}^{2+}$ triggered synaptic release, similar to what has been observed in the calyceal terminal at $<100 \mathrm{~Hz}$ (Forsythe et al., 1998; $\mathrm{Xu}$ and $\mathrm{Wu}, 2005$ ). The depression appears to reach a short-term steady-state level by about 10 stimuli for rates between 10 and $100 \mathrm{~Hz}$, consistent with the P/Q-type $\mathrm{Ca}^{2+}$ channel recovery time constant of seconds (Forsythe et al., 1998). At the endbulb synapses, AMPA receptor desensitization can be quite prominent especially in younger animals, but can also be detected in older animals (Chanda and Xu-Friedman, 2010). Cyclothiazide is reported to potentiate the paired pulse ratio (Bellingham and Walmsley, 1999; Yang and Xu-Friedman, 2008b) by reducing 
postsynaptic receptor desensitization (Chanda and Xu-Friedman, 2010; Yang and XuFriedman, 2008) as well as by affecting presynaptic release probability (Barnes-Davies and Forsythe, 1995; Bellingham and Walmsley, 1999). The effect of cyclothiazide on release probability has been suggested to be caused by a reduction of presynaptic $\mathrm{K}^{+}$currents in young rats (Ishikawa and Takahashi, 2001). Thus, it seems unlikely that CTZ acts on the $\mathrm{Ca}^{2+}$ channel directly to affect the release. Our data are consistent with this interpretation, because CTZ did not affect endbulb synaptic depression at stimulus rates less than $100 \mathrm{~Hz}$. When we reduced $\mathrm{Ca}^{2+}$ influx by partial block of $\mathrm{P} / \mathrm{Q}$ type $\mathrm{Ca}^{2+}$ channels, we observed a significant attenuation of synaptic depression at $25 \mathrm{~Hz}$, which could be explained by a reduction in $\mathrm{Ca}^{2+}$-dependent $\mathrm{P} / \mathrm{Q}$ type channel inactivation. At $100 \mathrm{~Hz}$, reducing $\mathrm{Ca}^{2+}$ influx resulted in initial synaptic facilitation followed by reduced depression. These observations are all consistent with the molecular mechanisms underlying $\mathrm{Ca}^{2+} /$ calmodulin-dependent $\mathrm{P} /$ $\mathrm{Q}$ type $\mathrm{Ca}^{2+}$ channel facilitation and inactivation (Lee et al., 2000; Lee et al., 2003).

\section{Functional consequences of reduced release probability during on-going spontaneous activity}

Synaptic transmission at mature endbulb terminals is a dynamically regulated process. Depression at rates higher than $100 \mathrm{~Hz}$ is predominately due to a depletion of the readily releasable pool of vesicles as well as receptor desensitization. The recovery from synaptic depression is accelerated by calcium accumulation in the presynaptic terminal (Wang and Manis, 2008; Yang and Xu-Friedman, 2008). In the present study, the recovery from lowrate synaptic depression should depend, in large part, on the rate at which the presynaptic $\mathrm{Ca}^{2+}$ channels recover from inactivation. In the MNTB calyx, the recovery from $\mathrm{Ca}^{2+}$ channel inactivation underlies the recovery of postsynaptic EPSC amplitudes after depression (Forsythe et al., 1998; Xu and Wu, 2005). Our study would suggest that in a normal acoustic environment where the synapses experience a wide range of firing rates, the majority, if not all, of endbulb synapses should operate in a depressed state. We observed increased PPR and reduced depression when we conditioned the endbulb with a Poissondistributed spike train. Modulating (reducing) release probability in chick endbulbs may be functionally beneficial to the reliability of postsynaptic responses (Brenowitz and Trussell, 2001). However, conditioning the endbulb with activity similar to the in vivo spontaneous rates, did not make the postsynaptic response more reliable when subsequently challenged at a higher rate. Although our conditioning data are roughly in agreement with results from similar experiments in MNTB neurons (Hermann et al., 2007), certain distinctions are worth noting. First, the convergence ratio of calyx-MNTB neuron is one-to-one, whereas the endbulb-bushy neuron convergence ratio is many-to-one (Oertel, 1985; Yang and $\mathrm{Xu}-$ Friedman, 2009). Second, endbulb synapses show higher release probability ( 0.5) at rest and have 50-100 estimated active release sites (Oleskevich et al., 2000; Oleskevich and Walmsley, 2002; Wang and Manis, 2005), whereas the quiescent release probability is lower $(\sim 0.2)$ but there are far more (800-1100) release sites (active zones) in the MNTB calyx (Koike-Tani et al., 2008; Taschenberger et al., 2002). Consequently, even though preconditioning is qualitatively detrimental to the reliability of postsynaptic neuron firing in both calyx and endbulb, a single calyx synapse in MNTB seems to be far more reliable than an endbulb in AVCN. Although the conditioning trains used in the MNTB were significantly longer than that used here (Hermann et al., 2007), firing reliability across the calyx ending does not fall below $50 \%$ until rates are greater than $500 \mathrm{~Hz}$, whereas in the endbulbs, entrainment for single fiber activation rapidly drops below $50 \%$ at $200 \mathrm{~Hz}$. Interestingly, the final response probabilities approached the same steady-state level regardless different ways of conditioning. These results are consistent with depletion and desensitization being the major modes of depression at high release rates, while the final steady-state level is determined by the interplay between depletion, desensitization, and $\mathrm{Ca}^{2+}$-facilitated recovery (Wang and Manis, 2008; Yang and Xu-Friedman, 2008). 
We find that when more than one terminal is activated simultaneously, postsynaptic responses are much more reliable ( $90 \%)$. In vivo, such nearly-simultaneously activated converging inputs should occur as a result of stimulus-induced correlated activities in the ANFs (Joris et al., 2006). However, converging endbulbs may not always be activated on the same cycle of the input waveform due to the independence of auditory nerve fiber firing. It has been shown that isolated individual endbulb terminals operate independently, i.e., synaptic depression of a given terminal is not influenced by activities in adjacent sibling terminals on the same bushy neuron (Yang and Xu-Friedman, 2009). Thus, with convergence, high response reliability could also be achieved through the shared contributions of independently-firing but only modestly-depressed presynaptic fibers.

\section{Abbreviations}

$\begin{array}{ll}\text { ACSF } & \text { artificial cerebrospinal fluid } \\ \text { ANF } & \text { auditory nerve fiber } \\ \text { CTZ } & \text { Cyclothiazide } \\ \text { DGG } & \text { D-glutamylglycine } \\ \text { EPSC } & \text { excitatory postsynaptic current } \\ \text { MNTB } & \text { medial nucleus of the trapezoid body } \\ \text { PPR } & \text { paired-pulse ratio } \\ \text { SR } & \text { spontaneous rates }\end{array}$

\section{Acknowledgments}

Supported by NIDCD grants R03DC008190 to YW and R01DC04551 to PBM.

\section{References}

Barnes-Davies M, Forsythe ID. Pre- and postsynaptic glutamate receptors at a giant excitatory synapse in rat auditory brainstem slices. J Physiol 1995;488:387-406. [PubMed: 8568678]

Bellingham MC, Walmsley B. A novel presynaptic inhibitory mechanism underlies paired pulse depression at a fast central synapse. Neuron 1999;23:159-170. [PubMed: 10402202]

Brenowitz S, David J, Trussell L. Enhancement of synaptic efficacy by presynaptic GABA(B) receptors. Neuron 1998;20:135-141. [PubMed: 9459449]

Brenowitz S, Trussell LO. Minimizing synaptic depression by control of release probability. $\mathrm{J}$ Neurosci 2001;21:1857-1867. [PubMed: 11245670]

Cao X, Oertel D. Excitatory inputs to bushy cells. Assoc Res Otolaryngol Midwinter meeting Abs\# 219. 2010

Chanda S, Xu-Friedman MA. A Low-affinity Antagonist Reveals Saturation and Desensitization in Mature Synapses in the Auditory Brainstem. J Neurophysiol 2010;103:1915-1926. [PubMed: 20107122]

Chaudhuri D, Issa JB, Yue DT. Elementary mechanisms producing facilitation of Cav2.1 (P/Q-type) channels. J Gen Physiol 2007;129:385-401. [PubMed: 17438119]

Farris HE, Wells GB, Ricci AJ. Steady-state adaptation of mechanotransduction modulates the resting potential of auditory hair cells, providing an assay for endolymph [Ca2+]. J Neurosci 2006;26:12526-12536. [PubMed: 17135414]

Forsythe ID, Tsujimoto T, Barnes-Davies M, Cuttle MF, Takahashi T. Inactivation of presynaptic calcium current contributes to synaptic depression at a fast central synapse. Neuron 1998;20:797807. [PubMed: 9581770] 
Hermann J, Pecka M, von Gersdorff H, Grothe B, Klug A. Synaptic transmission at the calyx of Held under in vivo like activity levels. J Neurophysiol 2007;98:807-820. [PubMed: 17507501]

Isaacson JS, Walmsley B. Counting quanta: direct measurements of transmitter release at a central synapse. Neuron 1995;15:875-884. [PubMed: 7576636]

Ishikawa T, Takahashi T. Mechanisms underlying presynaptic facilitatory effect of cyclothiazide at the calyx of Held of juvenile rats. J Physiol 2001;533:423-431. [PubMed: 11389202]

Iwasaki S, Takahashi T. Developmental changes in calcium channel types mediating synaptic transmission in rat auditory brainstem. J Physiol 1998;509:419-423. [PubMed: 9575291]

Joris PX, Louage DH, Cardoen L, van der Heijden M. Correlation index: a new metric to quantify temporal coding. Hear Res 2006;216-217:19-30.

Kachar B. Asymmetric illumination contrast: a method of image formation for video light microscopy. Science 1985;227:766-768. [PubMed: 3969565]

Kiang, NY. Discharge patterns of single fibers in the cat's auditory nerve. Cambridge, MA: MIT Press; 1965.

Koike-Tani M, Kanda T, Saitoh N, Yamashita T, Takahashi T. Involvement of AMPA receptor desensitization in short-term synaptic depression at the calyx of Held in developing rats. J Physiol 2008;586:2263-2275. [PubMed: 18339695]

Lee A, Scheuer T, Catterall WA. Ca2+/calmodulin-dependent facilitation and inactivation of P/Q-type Ca2+ channels. J Neurosci 2000;20:6830-6838. [PubMed: 10995827]

Lee A, Zhou H, Scheuer T, Catterall WA. Molecular determinants of $\mathrm{Ca}(2+) /$ calmodulin-dependent regulation of $\mathrm{Ca}(\mathrm{v}) 2.1$ channels. PNAS 2003;100:16059-16064. [PubMed: 14673106]

Liberman MC. Single-neuron labeling in the cat auditory nerve. Science 1982;216:1239-1241. [PubMed: 7079757]

Liberman MC, Oliver ME. Morphometry of intracellularly labeled neurons of the auditory nerve: correlations with functional properties. J Comp Neurol 1984;223:163-176. [PubMed: 6200517]

Lopez I, Ishiyama G, Acuna D, Ishiyama A, Baloh RW. Immunolocalization of voltage-gated calcium channel alpha1 subunits in the chinchilla cochlea. Cell Tissue Res 2003;313:177-186. [PubMed: 12845523]

Lorteije JA, Rusu SI, Kushmerick C, Borst JG. Reliability and precision of the mouse calyx of Held synapse. J Neurosci 2009;29:13770-13784. [PubMed: 19889989]

Nakamura T, Yamashita T, Saitoh N, Takahashi T. Developmental changes in calcium/calmodulindependent inactivation of calcium currents at the rat calyx of Held. J Physiol 2008;586:22532261. [PubMed: 18238813]

Oertel D. Synaptic responses and electrical properties of cells in brain slices of the mouse anteroventral cochlear nucleus. J Neurosci 1983;3:2043-2053. [PubMed: 6619923]

Oertel D. Use of brain slices in the study of the auditory system: spatial and temporal summation of synaptic inputs in cells in the anteroventral cochlear nucleus of the mouse. J Acoust Soc Am 1985;78:328-333. [PubMed: 2993393]

Oleskevich S, Clements J, Walmsley B. Release probability modulates short-term plasticity at a rat giant terminal. J Physiol 2000;524(Pt 2):513-523. [PubMed: 10766930]

Oleskevich S, Walmsley B. Synaptic transmission in the auditory brainstem of normal and congenitally deaf mice. J Physiol 2002;540:447-455. [PubMed: 11956335]

Raman IM, Trussell LO. The kinetics of the response to glutamate and kainate in neurons of the avian cochlear nucleus. Neuron 1992;9:173-186. [PubMed: 1352983]

Raman IM, Trussell LO. The mechanism of alpha-amino-3-hydroxy-5-methyl-4-isoxazolepropionate receptor desensitization after removal of glutamate. Biophys J 1995;68:137-146. [PubMed: 7711235]

Rodieck RW, Kiang NY, Gerstein GL. Some quantitative methods for the study of spontaneous activity of single neurons. Biophys J 1962;2:351-368. [PubMed: 14493108]

Roehm PC, Xu N, Woodson EA, Green SH, Hansen MR. Membrane depolarization inhibits spiral ganglion neurite growth via activation of multiple types of voltage sensitive calcium channels and calpain. Mol Cell Neurosci 2008;37:376-387. [PubMed: 18055215] 
Sewell WF. The relation between the endocochlear potential and spontaneous activity in auditory nerve fibres of the cat. J Physiol 1984;347:685-696. [PubMed: 6707972]

Sullivan JM. A simple depletion model of the readily releasable pool of synaptic vesicles cannot account for paired-pulse depression. J Neurophysiol 2007;97:948-950. [PubMed: 17079345]

Taberner AM, Liberman MC. Response properties of single auditory nerve fibers in the mouse. $\mathbf{J}$ Neurophysiol 2005;93:557-569. [PubMed: 15456804]

Taschenberger H, Leao RM, Rowland KC, Spirou GA, von Gersdorff H. Optimizing synaptic architecture and efficiency for high-frequency transmission. Neuron 2002;36:1127-1143. [PubMed: 12495627]

Tsuji J, Liberman MC. Intracellular labeling of auditory nerve fibers in guinea pig: central and peripheral projections. J Comp Neurol 1997;381:188-202. [PubMed: 9130668]

Wadiche JI, Jahr CE. Multivesicular release at climbing fiber-Purkinje cell synapses. Neuron 2001;32:301-313. [PubMed: 11683999]

Wang Y, Manis PB. Synaptic transmission at the cochlear nucleus endbulb synapse during age-related hearing loss in mice. J Neurophysiol 2005;94:1814-1824. [PubMed: 15901757]

Wang Y, Manis PB. Temporal coding by cochlear nucleus bushy cells in DBA/2J mice with early onset hearing loss. J Assoc Res Otolaryngol 2006;7:412-424. [PubMed: 17066341]

Wang Y, Manis PB. Short-term synaptic depression and recovery at the mature Mammalian endbulb of held synapse in mice. J Neurophysiol 2008;100:1255-1264. [PubMed: 18632895]

Wen B, Wang G, Dean I, Delgutte B. Dynamic range adaptation to sound level statistics in the auditory nerve. J. Neurosc 2009;29:13797-13808.

Wu XS, Xue L, Mohan R, Paradiso K, Gillis KD, Wu LG. The origin of quantal size variation: vesicular glutamate concentration plays a significant role. J Neurosci 2007;27:3046-3056. [PubMed: 17360928]

$\mathrm{Xu}$ J, He L, Wu LG. Role of $\mathrm{Ca}(2+)$ channels in short-term synaptic plasticity. Curr Opin Neurobiol 2007;17:352-359. [PubMed: 17466513]

$\mathrm{Xu} \mathrm{J,} \mathrm{Wu} \mathrm{LG.} \mathrm{The} \mathrm{decrease} \mathrm{in} \mathrm{the} \mathrm{presynaptic} \mathrm{calcium} \mathrm{current} \mathrm{is} \mathrm{a} \mathrm{major} \mathrm{cause} \mathrm{of} \mathrm{short-term}$ depression at a calyx-type synapse. Neuron 2005;46:633-645. [PubMed: 15944131]

Yang H, Xu-Friedman MA. Relative roles of different mechanisms of depression at the mouse endbulb of Held. J Neurophysiol 2008;99:2510-2521. [PubMed: 18367696]

Yang H, Xu-Friedman MA. Impact of synaptic depression on spike timing at the endbulb of held. J Neurophysiol 2009;102:1699-1710. [PubMed: 19587324]

Hear Res. Author manuscript; available in PMC 2011 December 1. 


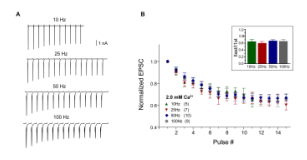

\section{Figure 1.}

Synaptic depression at 10-100 Hz. A, Exemplar traces of evoked EPSC trains in a bushy neuron activated at different rates. Traces are averages of 20-40 trials for each frequency with stimulus artifacts blanked out. B, Evoked EPSCs normalized to the amplitude of the first EPSC at 10, 25, 50 and $100 \mathrm{~Hz}$ shock stimulation in $2 \mathrm{mM}$ external $\left[\mathrm{Ca}^{2+}\right]$. Numbers in parentheses indicate cell numbers in each group. Inset: normalized EPSC at the end of 1115 pulse trains were $0.65 \pm 0.06,0.60 \pm 0.05,0.67 \pm 0.03$ and $0.66 \pm 0.05$ of the initial EPSC amplitude for $10,25,50$, and $100 \mathrm{~Hz}$ trains respectively $(p>0.05)$. 
A
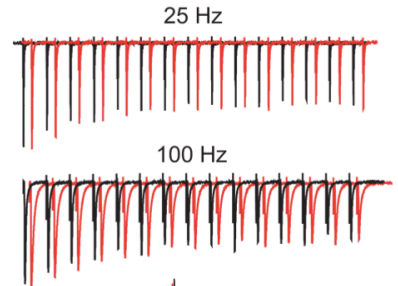

$\sqrt{\sqrt{50 \mathrm{uM} \mathrm{CTZ}}} \begin{gathered}\frac{1 \mathrm{nA}}{2 \mathrm{~ms}} \\ \text { Control }\end{gathered}$

B

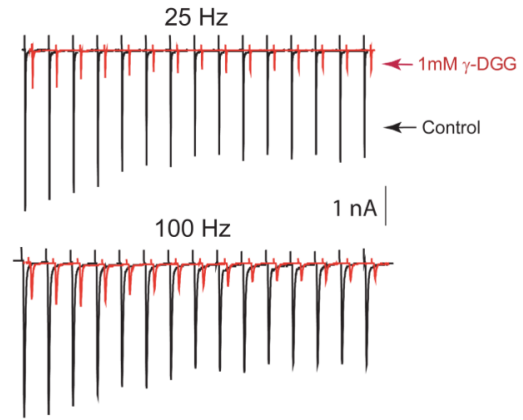

C

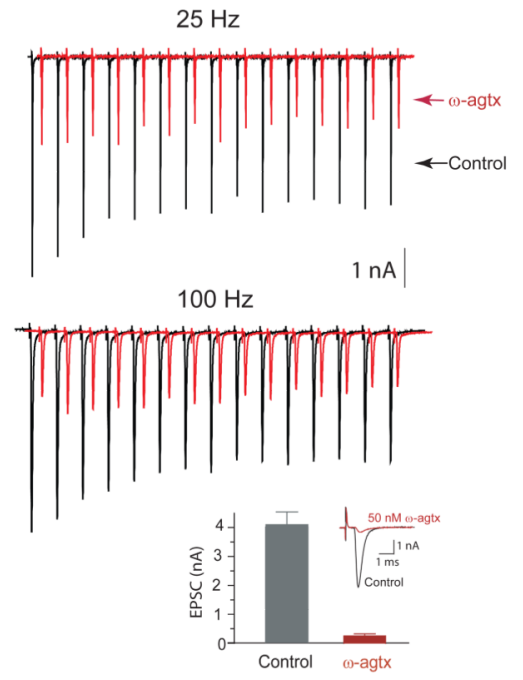

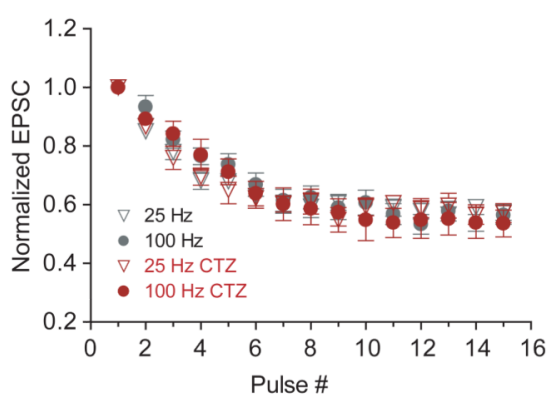
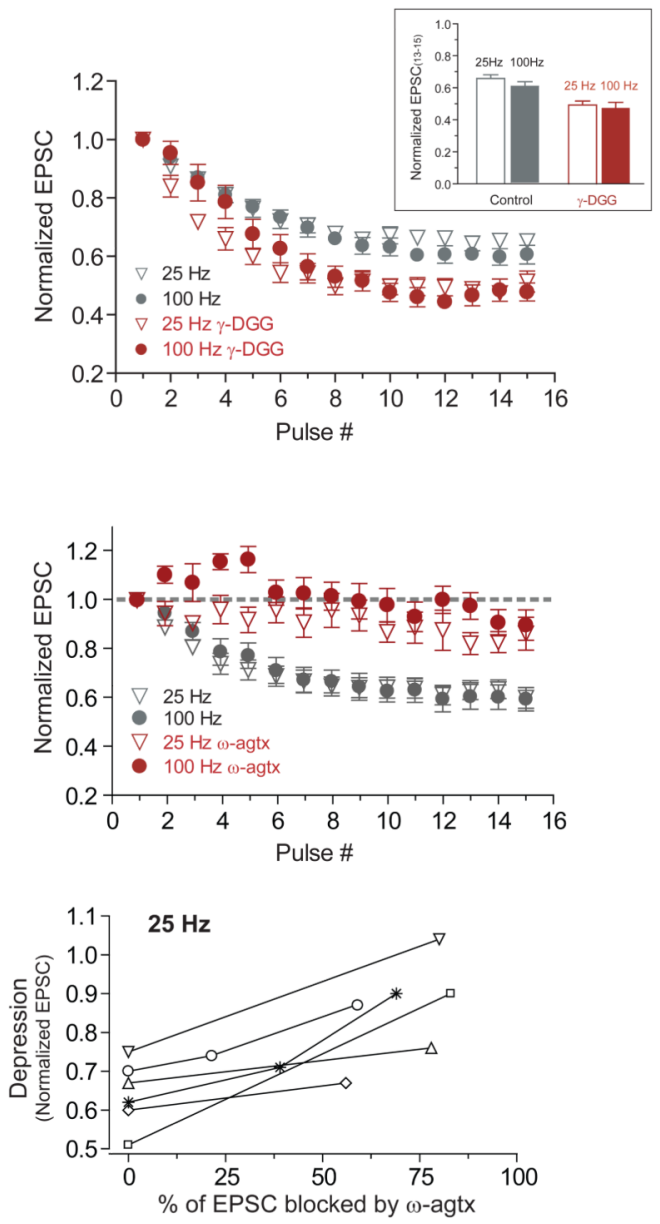

Figure 2.

Effects of cyclothiazide, $\gamma$-DGG and $\omega$-agatoxin IVA on endbulb synaptic transmission. A, Left: exemplar evoked EPSCs (average of 6 trials in all traces) at $25 \mathrm{~Hz}$ and $100 \mathrm{~Hz}$ from a bushy neuron in the presence (red) and absence (black) of $50 \mu \mathrm{M} \mathrm{CTZ}$. Bottom, expanded view of individual EPSCs with and without CTZ. Right: normalized EPSCs of 15 pulse trains at $25 \mathrm{~Hz}(p=0.95, \mathrm{n}=6$, paired $t$-test $)$ and $100 \mathrm{~Hz}(p=0.61)$ with and without CTZ. B, Left: Exemplar evoked EPSCs at $25 \mathrm{~Hz}$ and $100 \mathrm{~Hz}$ from a bushy neuron in the presence (red) and absence (black) of $1 \mathrm{mM} \gamma$-DGG. Absolute EPSC amplitudes were reduced by $\sim 70 \%$ in the presence of $1 \mathrm{mM} \gamma$-DGG. Right: normalized synaptic depressions were similar at the end of 15 pulse trains at $25 \mathrm{~Hz}$ and $100 \mathrm{~Hz}$ with $(\mathrm{p}=0.38, \mathrm{n}=5$, paired $t$-test $)$ and 
without ( $\mathrm{p}=0.22) 1 \mathrm{mM} \gamma$-DGG. C, Left: Exemplar evoked EPSCs before (black) and after (red) partial block of EPSCs by bath application of $\sim 40 \mathrm{nM} \omega$-agatoxin IVA. Bottom: EPSCs were $4.10 \pm 0.71 \mathrm{nA}$ (before) and $0.27 \pm 0.06 \mathrm{nA}$ (10 minutes after) bath application of $50 \mathrm{nM} \omega$-agatoxin IVA ( $\mathrm{p}=0.005, \mathrm{n}=5$, paired $t$-test). Right (top): normalized EPSCs of 15 pulse trains at $25 \mathrm{~Hz}(p<0.001, \mathrm{n}=6$, paired $t$-test $)$ and $100 \mathrm{~Hz}(p=0.001)$ with (red) and without (black) partial block of the synaptic transmission. Post-drug depression was measured after EPSC amplitude was blocked by more than $50 \%$ ( $71 \%$ on average). (Bottom): Attenuation of synaptic depression at the end of $25 \mathrm{~Hz}$ trains for individual neurons by $\omega$-agatoxin IVA. 
A

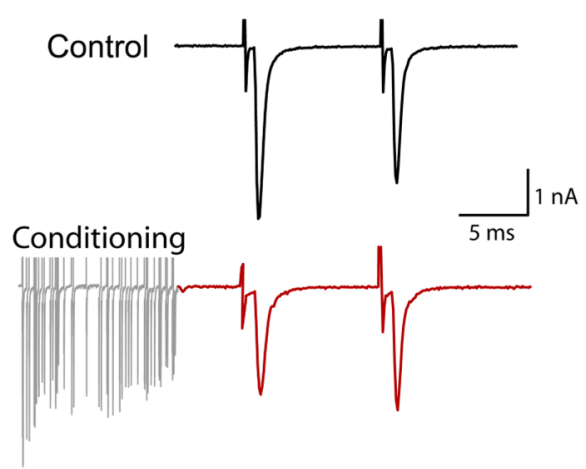

B

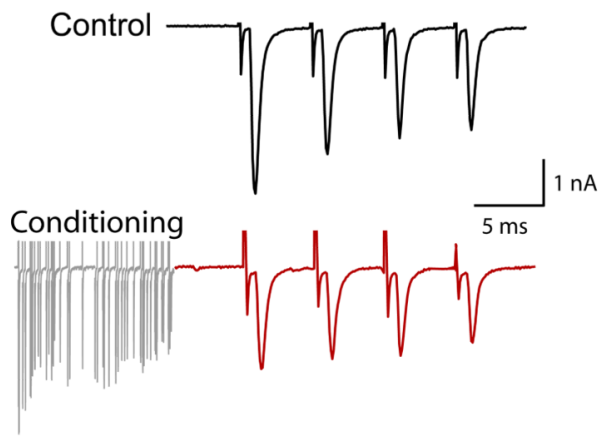

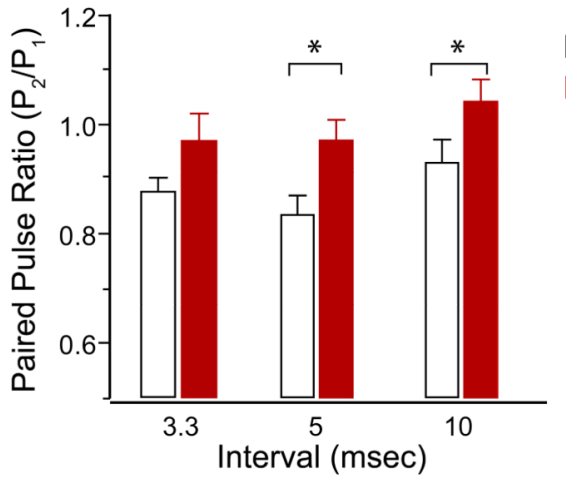

Control Post Poisson train

Figure 3.

Reduced release probability after $100 \mathrm{~Hz}$ Poisson-distributed spike trains. A, Left: exemplar EPSC paired-pulse traces from control (top) and after a $100 \mathrm{~Hz}$ Poisson conditioning train (red). Right: paired-pulse ratios at quiescence were $0.88 \pm 0.03,0.83 \pm 0.04$ and $0.93 \pm 0.04$ for $3.3,5$ and $10 \mathrm{~ms}$ intervals, whereas the PPRs increased to $0.97 \pm 0.05$ ( $p=0.061, \mathrm{n}=8$, 1-tailed $t$-test), $0.93 \pm 0.04(\mathrm{p}=0.011)$, and $1.04 \pm 0.04(\mathrm{p}=0.042)$ respectively for $3.3,5$ and $10 \mathrm{~ms}$ intervals after the $100 \mathrm{~Hz}$ Poisson trains. B, Left: exemplar EPSCs of 4 pulses $(200 \mathrm{~Hz})$ from control (top) and after a $100 \mathrm{~Hz}$ Poisson spike train (red). Right: normalized EPSC amplitudes for the 4 pulses at $200 \mathrm{~Hz}$ in control and after the Poisson conditioning trains ( $p<0.0001, \mathrm{n}=8,2$-way ANOVA, * denotes paired $t$-test $p<0.05$ for individual pulses.). 
A
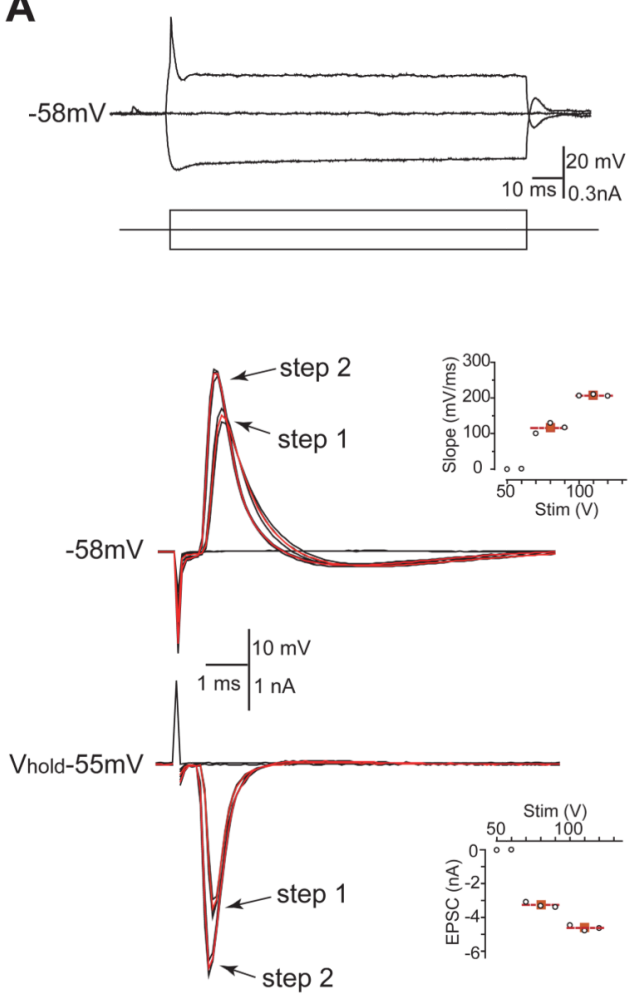

C

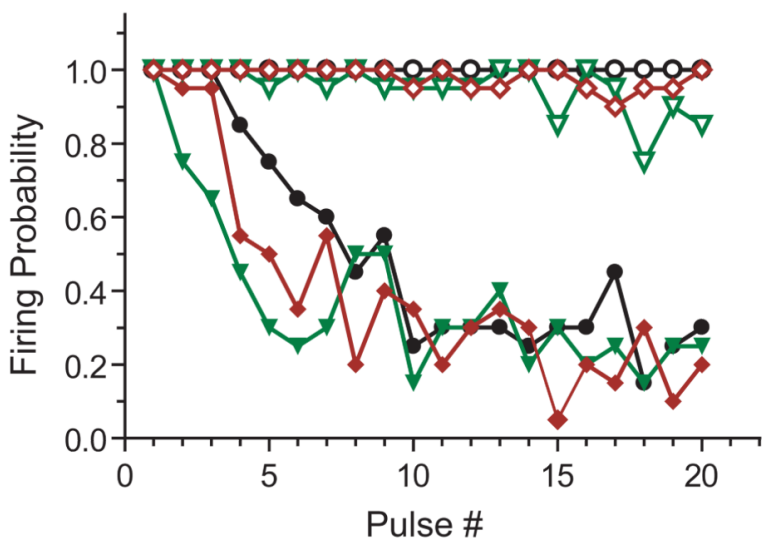

B

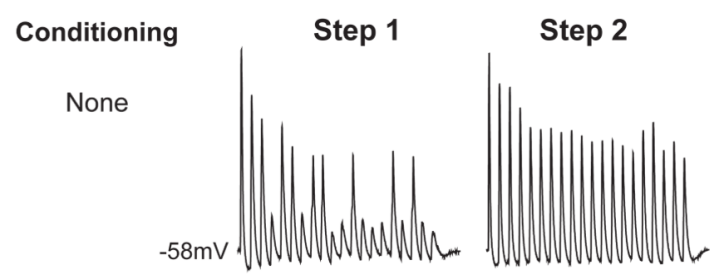

$25 \mathrm{~Hz}$
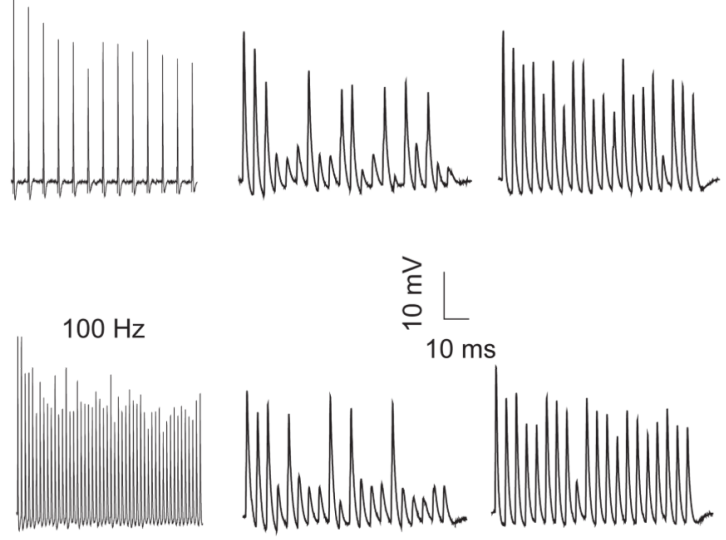

D

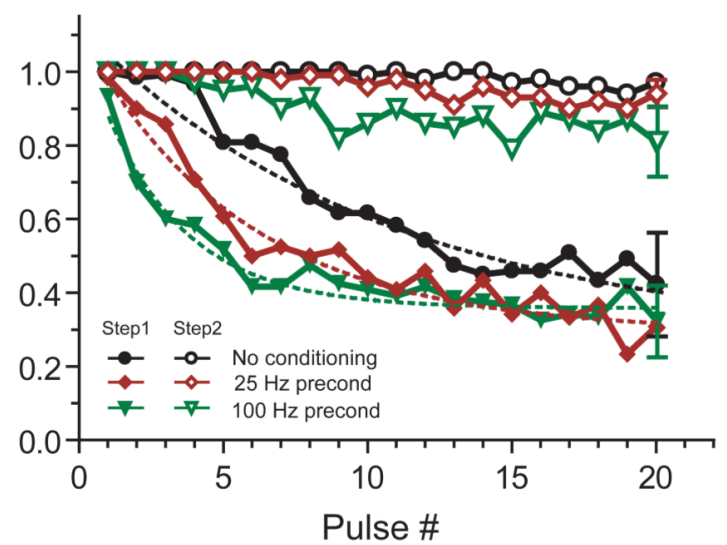

Figure 4.

Reliability of postsynaptic bushy neuron firing after conditioning trains. A, Bushy neurons were identified by their stereotypical onset response to a positive step current injection (top). With increasing auditory nerve stimulation, some bushy neurons showed a 2-step response pattern in both current-clamp (middle) and voltage-clamp (bottom). In this example neuron, the range of stimulus strength was 50-130V. In current-clamp, the step-1 action potential maximum rise slope was $115.4 \mathrm{mV} / \mathrm{ms}$ vs. $206.9 \mathrm{mV} / \mathrm{ms}$ for step-2 (middle, mean value for each step indicated by red filled squares); in voltage-clamp, the mean EPSC for step- 1 was $3.2 \mathrm{nA}$ vs. $4.6 \mathrm{nA}$ for step- 2 (bottom, $\mathrm{V}_{\mathrm{h}}=-55 \mathrm{mV}$ ). Red traces in current- and voltageclamp records were superimposed averages of step-1 and step-2 responses. B, Exemplar 
postsynaptic responses to a $200 \mathrm{~Hz}$ test stimulus train at step- 1 or step- 2 strength after conditioning the endbulb synapse with a $500 \mathrm{msec}$ train at 0,25 , and $100 \mathrm{~Hz}$. C, Calculated firing reliabilities to the $200 \mathrm{~Hz}$ test trains for the same neuron in B at step- 1 and 2 stimulus strengths after conditioning at 0,25 , and $100 \mathrm{~Hz}$. Legends in D applies in C. D, Group ( $n=6)$ data of the post conditioning firing reliabilities to the $200 \mathrm{~Hz}$ test trains. Dotted lines in step-1 curves were single exponential fits of the data. For clarity, error bars were omitted from the plot except on the last pulse in each condition. 